\title{
CARBON AND NITROGEN MINERALIZATION IN SOIL COMBINING SEWAGE SLUDGE AND STRAW
}

\author{
Sandro José Giacomini( ${ }^{(1)^{*}}$, Vera Lúcia Guedes Simon ${ }^{(2)}$, Celso Aita ${ }^{(1)}$, Leonardo Mendes \\ Bastos $^{(3)}$, Douglas Adams Weiler ${ }^{(1)}$ and Marciel Redin ${ }^{(4)}$
}

(1) Universidade Federal de Santa Maria, Departamento de Solos, Santa Maria, Rio Grande do Sul, Brasil.

(2) Prefeitura Municipal de Santa Maria, Secretaria de Município da Educação, Santa Maria, Rio Grande do Sul, Brasil.

(3) Universidade de Nebraska-Lincoln, Nebraska, Estados Unidos da América.

(4) Universidade Estadual do Rio Grande do Sul, Três Passos, Rio Grande do Sul, Brasil.

* Corresponding author.

E-mail: sjgiacomini@gmail.com

\begin{abstract}
The combined incorporation of sewage sludge (SS) and oat straw (OS) to the soil can increase straw carbon mineralization and microbial nitrogen immobilization. This hypothesis was tested in two laboratory experiments, in which SS was incorporated in the soil with and without OS. One treatment in which only straw was incorporated and a control with only soil were also evaluated. The release of $\mathrm{CO}_{2}$ and mineral $\mathrm{N}$ in the soil after organic material incorporation was evaluated for 110 days. The cumulative $C$ mineralization reached $30.1 \%$ for SS and $54.7 \%$ for OS. When these organic materials were incorporated together in the soil, straw $\mathrm{C}$ mineralization was not altered. About $60 \%$ of organic $\mathrm{N}$ in the SS was mineralized after 110 days. This $\mathrm{N}$ mineralization index was twice as high as that defined by Resolution 375/2006 of the National Environmental Council. The combined incorporation of SS and OS in the soil caused an immobilization of microbial $\mathrm{N}$ of $5.9 \mathrm{~kg} \mathrm{Mg}^{-1}$ of OS (mean $3.5 \mathrm{~kg} \mathrm{Mg}^{-1}$ ). The results of this study indicated that SS did not increase straw $\mathrm{C}$ mineralization, but the SS rate should be adjusted to compensate for the microbial $\mathrm{N}$ immobilization caused by straw.
\end{abstract}

Keywords: decomposition, $\mathrm{N}$ immobilization, biosolids. 


\title{
RESUMO: MINERALIZAÇÃO DE CARBONO E NITROGÊNIO COM A APLICAÇÃO COMBINADA DE LODO DE ESGOTO E PALHA NO SOLO
}

\begin{abstract}
A incorporação conjunta de lodo de esgoto (LE) e palha ao solo pode aumentar a mineralização do carbono da palha e a imobilização microbiana de nitrogênio. Essa hipótese foi avaliada em dois experimentos de laboratório em que o LE foi incorporado ao solo na presença e na ausência de palha de aveia. Um tratamento com somente palha incorporada e um tratamento-controle apenas com solo também foram avaliados. Durante 110 dias, foi avaliada a liberação de $\mathrm{CO}_{2}$ e o $\mathrm{N}$ mineral no solo, após a aplicação dos materiais orgânicos. A mineralização acumulada do C atingiu valor de 30,1\% no LE e de $54,7 \%$ na palha. Quando esses materiais orgânicos foram incorporados juntos ao solo, a mineralização do $C$ da palha não foi alterada. Aproximadamente $60 \%$ do $N$ orgânico presente no LE foi mineralizado em 110 dias. Esse índice de mineralização do $N$ é duas vezes maior do que aquele definido pela Resolução 375/2006 do Conselho Nacional do Meio Ambiente (Conama). A incorporação combinada de LE e palha no solo provocou imobilização microbiana de $N$ de $5,9 \mathrm{~kg} \mathrm{Mg}^{-1}$ de palha de aveia (média de $3,5 \mathrm{~kg} \mathrm{Mg}^{-1}$ ). Os resultados deste estudo indicaram que o LE não aumentou a mineralização do $C$ da palha, porém a dose de LE deve ser ajustada para compensar a imobilização microbiana de N induzida pela palha.
\end{abstract}

Palavras-chave: decomposição, imobilização de N, biossólido.

\section{INTRODUCTION}

Treatment of the urban-originated wastewater in a sewage treatment station generates an organic by-product called sewage sludge (SS). Chemical composition of SS is highly variable, mainly dependent on the origin of residual waters and type of depuration treatment. In Brazil, SS containing heavy metals, toxic organic compounds and pathogenic organisms below a given threshold set by Resolution 375/2006, issued by the National Environmental Council (Conama, 2006) is considered safe for agricultural use. However, even the application of SS considered safe under the above conditions is controlled by this Resolution due to its polluting potential, especially with regard to heavy metal accumulation in soil (Conama, 2006). Resolution 375/2006 defines that the maximum quantity of SS a given soil can receive in either one or more application events cannot exceed the maximum theoretical cumulative charge of inorganic substances. In the case of arsenic (As), for example, the maximum quantity of SS applied to a soil should not result in an application rate exceeding $30 \mathrm{~kg} \mathrm{ha}^{-1} \mathrm{As}$. Provided the regulation thresholds are met, application of SS to soil can both promote nutrient cycling and contribute to an increase in soil organic matter content, resulting in increased $\mathrm{C}$ sequestration. Furthermore, SS can be an important $\mathrm{N}$ source to plants due to its high $\mathrm{N}$ concentration (Gilmour et al., 2003).

An important aspect related to the agronomic use of SS is the definition of the maximum allowed soil application rate to maximize the fertilization and minimize the pollution potential. According to Resolution 375/2006 (Conama, 2006), application rates should be calculated based on the plant
$\mathrm{N}$ demand and available $\mathrm{N}$ from $\mathrm{SS}$. The latter considers the sum of mineral $\mathrm{N}$ present in SS at the time of application and the organic $\mathrm{N}$ mineralizable fraction (MF). In Resolution 375/2006, the MF value of both aerobically and anaerobically digested SS is 30 and $20 \%$, respectively. These MF values are based on studies that evaluated $\mathrm{N}$ mineralization from SS incorporated to soil without plant residues (Serna and Pomares, 1992; Hernández et al., 2002; Gilmour et al., 2003; Doublet et al., 2010). Considering that SS application to annual crops can be performed over plant residue followed by incorporation, it is necessary to evaluate the effect of this practice on soil $\mathrm{N}$ availability after SS application. This is due to the fact that crop residues normally have high $\mathrm{C} / \mathrm{N}$ ratio levels (low $\mathrm{N}$ level). Under this condition, the mixture between $\mathrm{N}$-rich SS and crop residues can result in SS-N immobilization by the microbial biomass during crop residues decomposition (Recous et al., 1995; Aita et al., 2012), causing a reduction in soil $\mathrm{N}$ availability. Therefore, the SS recommendation in this scenario must be adapted to improve its efficiency as $\mathrm{N}$ fertilizer.

The combined application of SS and crop residues could also increase decomposition of the latter due to increased $\mathrm{N}$ availability (Recous et al., 1995) provided by SS. An increase in crop residue decomposition could result in increased $\mathrm{CO}_{2}$ emission and less $\mathrm{C}$ remaining in the soil. This aspect also needs to be evaluated under this new scenario of SS use. Due to the close relationship between $\mathrm{C}$ and $\mathrm{N}$ biotransformation cycles, it is important to evaluate the dynamics of both elements after SS application to soil with crop residues. The objective of this study was to evaluate soil $\mathrm{C}$ and $\mathrm{N}$ mineralization after SS application in the presence and absence of oat straw (OS) incorporated into the soil. 


\section{MATERIAL AND METHODS}

This study consisted of two laboratory experiments. An Argissolo Vermelho Distrófico arênico (Hapludalf) was collected from the 0.0-0.10 m layer of a no-tillage area under soybean-oat succession. The soil contained $150 \mathrm{~g} \mathrm{~kg}^{-1}$ clay, $5.3 \mathrm{pH}$ (water) and $17 \mathrm{~g} \mathrm{~kg}^{-1}$ organic matter. After sampling, the soil was sieved $(<4.75 \mathrm{~mm})$, ground and stored in a dark plastic bag, at room temperature, for four days before incubation.

Sewage sludge (SS) was collected at the Sewage Treatment Station of Santa Maria, RS, of the Companhia Riograndense de Saneamento (CORSAN, Rio Grande do Sul State Sanitation Agency). The sludge was processed in an extended aerobical sewage activation system and continuous flow. After treatment, the SS was deposited in drying pools, from where a sample of about $10 \mathrm{~kg}$ of SS was collected, placed in a plastic bucket with lid and taken to the laboratory. After homogenization, three SS subsamples were taken from the bucket for physical and chemical characterization. Dry matter (DM) was determined by oven-drying of about 50 $\mathrm{g}$ of $\mathrm{SS}$ at $65{ }^{\circ} \mathrm{C}$ to constant weight. The $\mathrm{pH}$ was measured directly in an aliquot of about $12 \mathrm{~g}$ fresh SS. After DM determination, the three subsamples were finely ground for total $\mathrm{C}$ determination by dry combustion in an elemental analyzer (model FlashEA 1112, Thermo Finnigan, Milan, Italy). Total N was determined in fresh SS by the Kjeldahl method (Tedesco et al., 1995). Fresh SS ammoniacal N $\left(\mathrm{NH}_{3}\right.$ $+\mathrm{NH}_{4}^{+}$) was determined by adding $20 \mathrm{~mL}$ water and $\mathrm{MgO}$ to each sample followed by distillation. Nitric $\mathrm{N}$ $\left(\mathrm{NO}_{2}^{-}+\mathrm{NO}_{3}^{-}\right)$was quantified by adding $0.2 \mathrm{~g}$ Devarda alloy to each of the samples that had been previously used for ammoniacal $\mathrm{N}$ determination, followed by distillation (Tedesco et al., 1995).

Black-oat straw (OS) was collected at physiological maturity from an experiment in an area of the Soil Department of the Federal University of Santa Maria. After sampling, the shoots were air-dried and stored until incubation. Before the beginning of incubation, straw samples were oven-dried at
$65{ }^{\circ} \mathrm{C}$ to constant weight. Total $\mathrm{C}$ and $\mathrm{N}$ levels were determined in the dried and ground material with the above-mentioned elemental analyzer. Selected characteristics of SS and straw are shown in table 1.

Mineralization of $\mathrm{C}$ and $\mathrm{N}$ of SS, OS and the mixture of both, all incorporated into the soil, was measured. In a completely randomized design with four replications, the following treatments were evaluated: T1 - Soil (S); T2 - Soil + SS incorporated (S + SSi); T3 - Soil + OS incorporated $(\mathrm{S}+\mathrm{OSi})$; and $\mathrm{T} 4$ - Soil + $\mathrm{SSi}+\mathrm{OSi}$. Containers with soil and applied treatments were incubated for 110 days, in the dark, at $25^{\circ} \mathrm{C}$. Soil moisture was adjusted to approximately $80 \%$ field capacity and maintained at this level throughout the incubation period by adding water periodically.

The $\mathrm{N}$ mineralization experiment had a total of 112 units (four treatments $\times$ seven evaluation dates $\times$ four replications) of acrylic containers (diameter $0.05 \mathrm{~m}$, volume $110 \mathrm{~mL}$ ). The $\mathrm{C}$ mineralization experiment consisted of 16 units (four treatments $\times$ four replications), using the above containers.

For the $\mathrm{C}$ and $\mathrm{N}$ mineralization studies, the experimental unit setup followed the same scheme. Each container received $133.1 \mathrm{~g}$ soil at $13 \%$ water content (98.2 g dry soil) and was compacted to a height of $0.05 \mathrm{~m}$ to achieve bulk density of $1.2 \mathrm{Mg} \mathrm{m}^{-3}$. Straw and SS was incorporated into the soil before filling the containers. Dried OS was manually cut to pieces (length $10-20 \mathrm{~mm}$ ) and added $(600 \mathrm{mg}$ per container, corresponding to $3 \mathrm{Mg} \mathrm{ha}^{-1}$ of dried OS). Fresh SS was added to the soil at a rate of $30 \mathrm{Mg} \mathrm{ha}^{-1}$. The quantities of DM, C and $\mathrm{N}$ added to the soil with the organic materials are presented in table 1.

Acrylic containers used for $\mathrm{N}$ mineralization were placed in groups of four (treatment replications) within a $1.7 \mathrm{~L}$ glass container with lid. In this way, all 96 acrylic containers were placed as described within 24 glass containers. Acrylic containers used for $\mathrm{C}$ mineralization were conditioned individually within $800 \mathrm{~mL}$ glass containers equipped with pressured lid. To avoid $\mathrm{O}_{2}$ deficit, all glass containers for both $\mathrm{C}$ and $\mathrm{N}$ mineralization evaluation were periodically aerated for $10 \mathrm{~min}$. Soil moisture was

Table 1. Dry matter (DM), total carbon (C) and nitrogen (N) concentration and quantities added to soil by sewage sludge (SS) and oat straw (OS)

\begin{tabular}{|c|c|c|c|c|c|c|c|c|}
\hline Organic material & $\mathrm{DM}^{(1)}$ & Total $C^{(2)}$ & Total N $\mathrm{N}^{(3)}$ & Ammonia N & Nitric N & Organic N & $\mathrm{C} / \mathrm{N}$ & pH \\
\hline & \multicolumn{6}{|c|}{$\mathrm{g} \mathrm{kg}^{-1}$} & & \\
\hline SS & 70 & 21.7 & 4.03 & 0.59 & 0.01 & 3.43 & 5.4 & 6.8 \\
\hline \multirow[t]{2}{*}{ OS } & 1,000 & 409.9 & 4.93 & - & - & - & 71.0 & \\
\hline & \multicolumn{6}{|c|}{$\mathrm{mg} \mathrm{kg}^{-1}$} & & \\
\hline SS & 3,505 & 1,086 & 201.8 & 29.6 & 0.5 & 171.7 & - & - \\
\hline OS & 5,093 & 2,087 & 25.1 & - & - & - & - & - \\
\hline
\end{tabular}

(1) DM, C and N values are on a wet basis; C and N values on SS DM determined on elemental analyzer were 310.2 and $54.4 \mathrm{~g} \mathrm{~kg}^{-1}$, respectively. ${ }^{(2)}$ Total C: determined by dry combustion in an elemental analyzer. ${ }^{(3)}$ Total N: Kjeldahl method (Tedesco et al., 1995). 
controlled by weighing each experimental unit and adding water when necessary using a pipette.

Mineralization of $\mathrm{N}$ from the treatments was assessed by evaluating soil mineral $\mathrm{N}\left(\mathrm{NH}_{4}^{+}\right.$and $\mathrm{NO}_{2}^{-}+\mathrm{NO}_{3}^{-}$) periodically. Mineral $\mathrm{N}$ was determined at 0 ( $2 \mathrm{~h}$ after incubation initiation), $7,14,21,35$, 60 , and 110 days after incubation initiation. On each date, mineral $\mathrm{N}$ from 16 acrylic containers was determined. Soil mineral $\mathrm{N}$ was extracted using a $1 \mathrm{~mol} \mathrm{~L}^{-1} \mathrm{KCl}$ solution and further distilled after addition of $\mathrm{MgO}$ and Devarda's alloy to determine $\mathrm{NH}_{4}^{+}+\mathrm{NO}_{2}^{-}+\mathrm{NO}_{3}^{-}$(Tedesco et al., 1995).

Mineralization of $\mathrm{C}$ from $\mathrm{SS}$ and $\mathrm{OS}$ was evaluated by quantifying $\mathrm{CO}_{2}$ release (Stotzky, $1965)$ at $2,4,6,10,14,21,28,35,45,60,75,86$, and 110 days after incubation initiation from the same flasks. In addition to all glass containers used to store the $\mathrm{CO}_{2}$ released from the experimental units, there were four glass containers in which an empty acrylic container was placed to serve as a blank and used to determine $\mathrm{CO}_{2}$ concentration in air. Released $\mathrm{CO}_{2}$ from each treatment and blanks was captured using $10 \mathrm{~mL}$ of $\mathrm{NaOH} 1 \mathrm{~mol} \mathrm{~L}^{-1}$ solution, which was placed in a glass flask internally suspended in the headspace of each glass container. On each sampling date, excess $\mathrm{NaOH}$ was titrated with $\mathrm{HCl} 1 \mathrm{~mol} \mathrm{~L}^{-1}$ solution following carbonate precipitation with the use of $\mathrm{BaCl}_{2} 1 \mathrm{~mol} \mathrm{~L}^{-1}$ solution. After containers had been aerated for 10 min on each sampling date, a new flask containing $1 \mathrm{~mol} \mathrm{~L}^{-1} \mathrm{NaOH}$ solution was suspended within each glass container.

Apparent C mineralization from SS and OS was calculated by subtracting the quantity of $\mathrm{CO}_{2}$ - $\mathrm{C}$ emitted by the treatment containing only soil $(\mathrm{S})$ by the quantity of $\mathrm{CO}_{2}-\mathrm{C}$ emitted by each treatment ( $\mathrm{SSi}$, OSi and $\mathrm{SSi}+\mathrm{OSi}$ ) as described by Giacomini et al. (2008). Apparent N mineralization was calculated using the equation adopted by Giacomini et al. (2013):

$$
N M=(N o r 2-N o r 1)-(N s 2-N s 1)
$$

where NM is the $\mathrm{N}$ mineralization $\left(\mathrm{mg} \mathrm{kg}^{-1}\right)$; Nro1 and Nro2 are the quantities of soil mineral $\mathrm{N}$ $\left(\mathrm{mg} \mathrm{kg}^{-1}\right)$ in treatments with organic materials ( $\mathrm{SSi}$, $\mathrm{OSi}$ and $\mathrm{SSi}+\mathrm{OSi}$ ) at the beginning and end of each evaluation interval, respectively; and $\mathrm{Ns}_{\mathrm{s}}$ and Ns2 are the quantities of soil mineral $\mathrm{N}\left(\mathrm{mg} \mathrm{kg}^{-1}\right)$ on the $\mathrm{S}$ treatment at the beginning and end of each evaluation interval, respectively. Values of NM used on the present study are equivalent to the MF index on Resolution 375/2006 from Conama (Conama, 2006). Values obtained for $\mathrm{C}$ and $\mathrm{N}$ mineralization are considered apparent since it is assumed that amending soil with SS and OS does not affect $\mathrm{C}$ and $\mathrm{N}$ mineralization from soil organic matter (priming effect). Results were subjected to analysis of variance and treatment means were compared using Tukey test at $5 \%$.

\section{RESULTS AND DISCUSSION}

\section{Carbon mineralization}

Addition of organic material to soil caused an increase in microbial activity, since an increase in $\mathrm{CO}_{2}$ release from treatments was observed when compared to the control (Figure 1). Cumulative $\mathrm{CO}_{2}$ released $\left(\mathrm{mg} \mathrm{kg}^{-1}\right.$ of $\left.\mathrm{CO}_{2}-\mathrm{C}\right)$ differed among treatments at the end of the experiment, decreasing in the order: $\mathrm{S}+\mathrm{OSi}+\mathrm{SSi}(1,673)>\mathrm{S}+\mathrm{OSi}(1,360)>\mathrm{S}$ + SSi (585) $>$ S (237). Differences can be attributed to different $\mathrm{C}$ quantities added on each treatment and also by the ease of $\mathrm{C}$ utilization from organic materials for microbial biosynthesis and energy production. The quantity of $\mathrm{C}$ added to the soil with OS was approximately twice as high as that added with SS (Table 1).

The effect of OS and SS on soil microbial activity can be visualized by the rate of $\mathrm{C}$ mineralization (rCmin) (Figure 1b). On the first sampling date $(2 \mathrm{~d}$

(a)

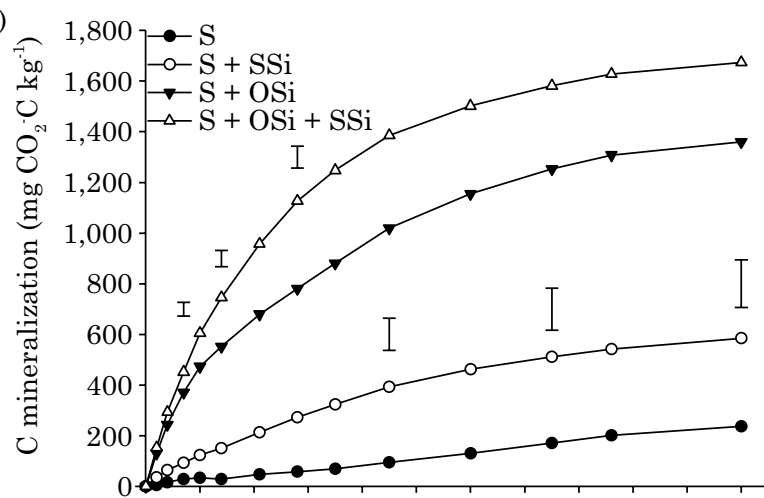

(b)

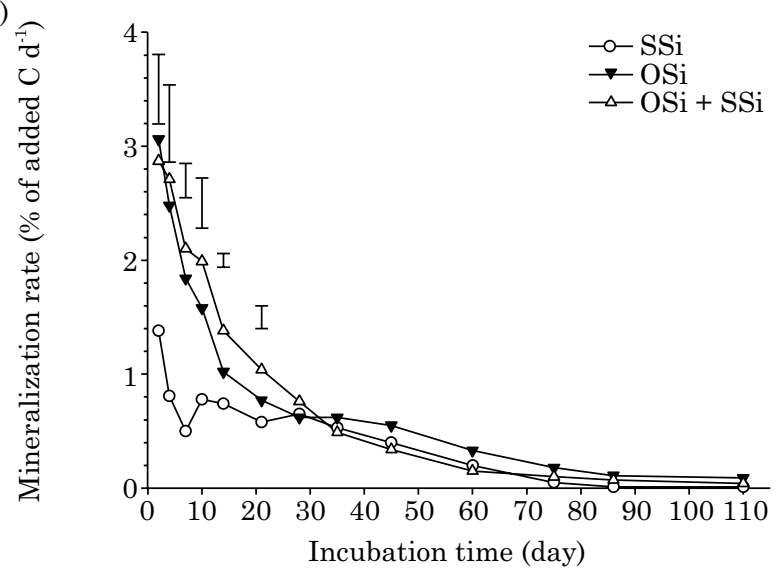

Figure 1. Cumulative $\mathrm{C}$ mineralization (a) and mineralization rate (b) during the incubation of sewage sludge (SS) and oat straw (OS) incorporated (i) into soil (S) combined or alone. Vertical bars represent the minimum significant difference between treatment means (Tukey at $5 \%$ ). 
after incubation initiation), $\mathrm{rCmin}$ from incorporated straw was $3.06 \%$ added $\mathrm{C} \mathrm{d}^{-1}$ compared to only $1.38 \%$ added $\mathrm{C} \mathrm{d}^{-1}$ from incorporated SS. This difference remained significantly higher in the OS treatment when compared to the SS treatment during the first 14 days. This evidences that organic compounds from OS were more easily utilized by microbes than those from SS, despite the fact that $\mathrm{SS}$ had a $\mathrm{C} / \mathrm{N}$ ratio 13 times lower than OS (Table 1 ). In a greenhouse study, Rowell et al. (2001) observed that wheat straw with a $\mathrm{C} / \mathrm{N}$ ratio of 49 had higher decomposition rates than aerobic SS with a $\mathrm{C} / \mathrm{N}$ of 8 . Based on $\mathrm{C} / \mathrm{N}$ ratio values, one can state that C mineralization from SS was not limited by $\mathrm{N}$ availability but by readily available decomposable C. The SS used on this study was treated by the prolonged aeration activated sludge method, which promotes SS stabilization in the tank by intense microbial biomass endogenous and exogenous respiration (Sperling, 1997).

The rCmin of organic materials decreased from the first sampling date, after two days. The reduction of $\mathrm{rCmin}$ was intensified during the first 14 days in both treatments where OS was incorporated into the soil, with (OSi $+\mathrm{SSi})$ and without (OSi) SS and during the first six days, when SS was applied alone (SSi). Figure 1 shows that in most treatments, rCmin was less than $1 \%$ added $\mathrm{C} \mathrm{d}^{-1}$ after 18 days and less than $0.6 \%$ added $\mathrm{C} \mathrm{d}^{-1}$ after 45 days. Considering that temperature and moisture were constant throughout incubation, the observed $\mathrm{C}$ mineralization patterns can be attributed to sequential microbial utilization of organic compounds from OS and SS according to their quality. Labile organic compounds present mainly in the water-soluble fraction are rapidly assimilated by microorganisms, increasing microbial biomass and $\mathrm{CO}_{2}$ release during the initial stages of decomposition (Reinertsen et al., 1984). As these compounds become scarce, a stepwise succession of microbial populations specialized in increasingly more recalcitrant $\mathrm{C}$ sources is observed (Swift et al., 1979). Thus, results (Figure 1) indicate a higher proportion of easily degradable $\mathrm{C}$ compounds in straw than in $\mathrm{SS}$, despite the high $\mathrm{C} / \mathrm{N}$ ratio of straw. Therefore, at the same $\mathrm{C}$ rates applied to the soil by both organic materials, straw will play an important role in supporting microbial activity whereas SS could contribute more significantly to increase soil organic matter (SOM).

After subtracting the cumulative $\mathrm{CO}_{2}$ emission from the control (S) from each treatment (OSi, $\mathrm{SSi}$ and $\mathrm{OSi}+\mathrm{SSi}$ ), it was observed that the cumulative $\mathrm{CO}_{2}$ release from $\mathrm{OSi}+\mathrm{SSi}$ at 110 days $\left(1,436 \mathrm{mg} \mathrm{CO} \mathrm{CO}_{2}-\mathrm{C} \mathrm{kg}^{-1}\right)$ was similar to the combined $\left(1,471 \mathrm{mg} \mathrm{CO}_{2}-\mathrm{C} \mathrm{kg}^{-1}\right) \mathrm{CO}_{2}$ release from treatments SSi and Si alone (348 and 1,123 $\mathrm{mg} \mathrm{CO}_{2}-\mathrm{C} \mathrm{kg}^{-1}$, respectively) (Figure 1a). Therefore, SS incorporated along with OS did not affect straw $\mathrm{C}$ mineralization. Aita et al. (2012), under laboratory conditions, observed no effect of incorporated pig slurry on wheat $\mathrm{C}$ mineralization $(\mathrm{C} / \mathrm{N}$ of 69$)$.

With increased $\mathrm{N}$ availability resulting from SS addition in our study along with results from pig slurry in a study by Aita et al. (2012), we expected an increase in straw $\mathrm{C}$ mineralization. With straw incorporation, soil contact is favored, which allows higher microbial accessibility to the $\mathrm{C}$ source. With higher $\mathrm{C}$ accessibility, microbial $\mathrm{N}$ demand also increases, which, in this study, could be met by SS, once approximately $15 \%$ of total $\mathrm{N}$ applied with SS was already in the mineral form (Table 1). The explanation of Aita et al. (2012) for not observing the same effect with pig slurry (62\% of total $\mathrm{N}$ in mineral form), was that the microbial $\mathrm{N}$ need was met to a lesser extent by straw $\mathrm{N}$, and to a higher extent by SOM mineralized $\mathrm{N}$.

Apparent $\mathrm{C}$ mineralization from organic materials, expressed in relation to added $\mathrm{C}$ to soil, shows a distinct pattern of $\mathrm{C}$ mineralization from OS and SS, mainly during the first 45 days after incubation initiation (Figure 2). For SS, C mineralization increased linearly during the first 45 days, emitting $86 \%$ of total cumulative $\mathrm{C}$ mineralized at the end of the experiment (110 days). For OS, C mineralization was non-linear, with mineralization rates decreasing over time. In contrast to what was observed in this study with SS, Doublet et al. (2010) found a curvilinear response of $\mathrm{C}$ mineralization from aerobic SS, with $80 \%$ of total cumulative C mineralized in 91 days being released during the first 14 days. This difference between the SS and OS mineralization patterns must be related to differences in the substrate biochemical composition, ultimately affecting the soil microbial activity.

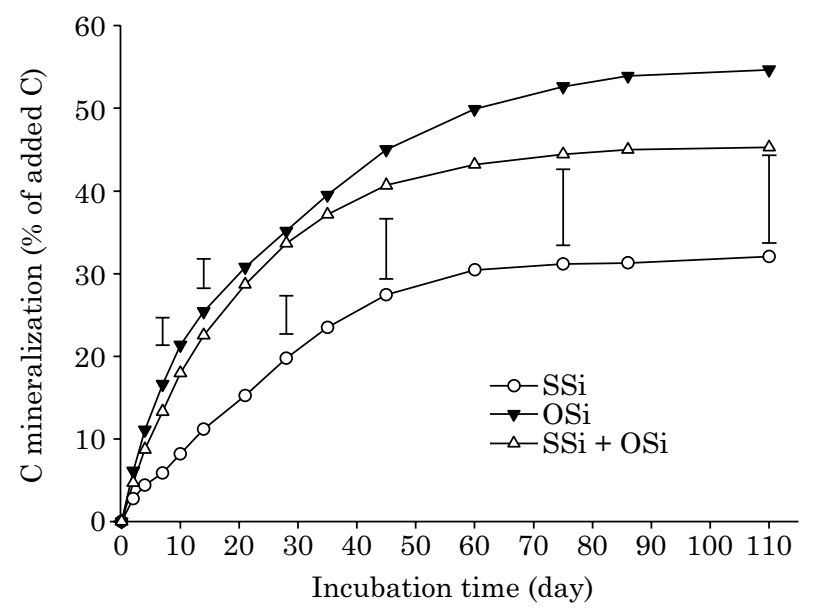

Figure 2. Cumulative $\mathrm{C}$ mineralization during the incubation of sewage sludge (SS) and oat straw (OS) incorporated (i) into soil (S) combined or alone. Vertical bars represent the minimum significant difference between treatment means (Tukey at $5 \%$ ). 
After 110 days of incubation, $\mathrm{C}$ mineralization from SS was significantly lower than that from OS. In the treatment with SS alone, cumulative $\mathrm{C}$ mineralization was 30.1 and $54.7 \%$ for OS (Figure 2). This lower $\mathrm{C}$ mineralization from $\mathrm{SS}$ is in agreement with other studies that used aerobically treated SS (Rowell et al., 2001; Gilmour et al., 2003; Andrade et al., 2006; Doublet et al., 2010), explained by the higher content of recalcitrant $\mathrm{C}$ present in the organic material resulting from urban centers of residual water treatment. When SS was applied together with OS, the cumulative $\mathrm{C}$ mineralization reached $45.3 \%$ of the total $\mathrm{C}$ added in the mixture. Based on the comparison between cumulative C mineralization of SS and OS (Figure 2), it can be estimated that for each $\mathrm{Mg}$ of $\mathrm{C}$ added to the soil with both materials, the quantity of $\mathrm{C}$ in soil after 110 days would be 695,494 and $547 \mathrm{~kg}$, for SSi, OSi and SSi $+\mathrm{Si}$, respectively. This shows that continuous SS application is more effective than OS in recovering SOM stocks and promoting soil $\mathrm{C}$ sequestration.

\section{Nitrogen mineralization}

On the first sampling day, $2 \mathrm{~h}$ after incubation initiation, mineral $\mathrm{N}$ from treatments receiving SS was $15.5 \mathrm{mg} \mathrm{kg}^{-1} \mathrm{~N}$ higher than in the control treatment (Figure 3). This difference represents almost half of the mineral $\mathrm{N}$ applied to the soil with $\mathrm{SS}$, which was $29.6 \mathrm{mg} \mathrm{kg}^{-1}$ (Table 1). Hernández et al. (2002) observed similar results using two rates of aerobic SS applied to two soil types, resulting in a mean mineral N recovery from SS application of $75 \%$ $\left(24.2 \mathrm{mg} \mathrm{kg}^{-1} \mathrm{~N}\right)$. Ammonium $\mathrm{N}$ adsorption by the soil clay fraction and $\mathrm{N}$ losses by $\mathrm{NH}_{3}$ volatilization during the experiment could be possible causes for the mineral N recovery resulting from SS.

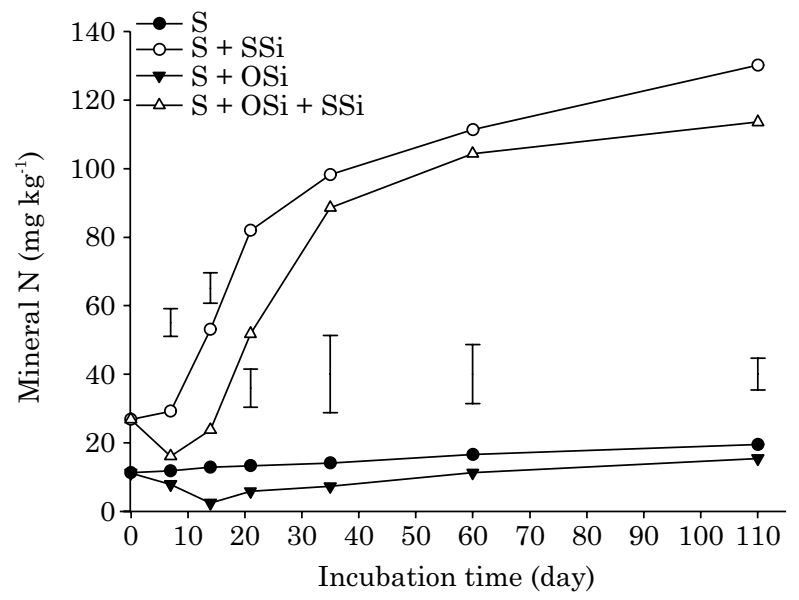

Figure 3. Amounts of mineral $\mathrm{N}$ during the incubation of sewage sludge (SS) and oat straw (OS) incorporated (i) into soil (S) combined or alone. Vertical bars represent the minimum significant difference between treatment means (Tukey at $5 \%$ ).
Nitrogen mineralization results indicate that only the treatment with SSi maintained a positive N net mineralization rate throughout the experiment (Figure 3). Nitrogen mineralization from SS was slow during the first week of incubation and increased thereafter to a rate of $3.6 \mathrm{mg} \mathrm{kg}^{-1} \mathrm{~d}^{-1}$ until the $35^{\text {th }}$ day. After this period, mineralization rates decreased again, stabilizing at $0.35 \mathrm{mg} \mathrm{kg}^{-1} \mathrm{~d}^{-1} \mathrm{~N}$ until the end of incubation. When SS was applied alone, $56 \%\left(52.9 \mathrm{mg} \mathrm{kg}^{-1} \mathrm{~N}\right)$ of the total cumulative $\mathrm{N}$ mineralized after 110 days $\left(94.5 \mathrm{mg} \mathrm{kg}^{-1} \mathrm{~N}\right)$ had already been mineralized, during the first three weeks (Figure 3). This N mineralization pattern from SS has been observed in other studies where aerobic SS was used (Hernández et al., 2002; Doublet et al., 2010), possibly due to the presence of $\mathrm{N}$ compounds of different degrees of resistance to microbial decomposition in this organic material. During the first 35 days the more labile fractions must have been mineralized, followed thereafter by the more recalcitrant fractions.

Comparing treatments $\mathrm{SSi}$ and $\mathrm{OSi}+\mathrm{SSi}$, one can observe the effect of the OS application on SS-N mineralization (Figure 3). The $\mathrm{N}$ mineral curve of OSi + SSi was always below that of SSi, indicating less net $\mathrm{N}$ mineralization due to $\mathrm{N}$ immobilization caused by the presence of OS. Maximum difference between these treatments was observed after 21 days, when $\mathrm{N}$ immobilization caused by OS reached $30 \mathrm{mg} \mathrm{kg}^{-1}$ (55\% mineral $\mathrm{N}$ in $\mathrm{SSi}$ ). This value is similar to that observed by Aita et al. (2012), who found $39 \mathrm{mg} \mathrm{kg}^{-1}$ when evaluating soil $\mathrm{N}$ dynamics after pig slurry and wheat straw application ( $\mathrm{C} / \mathrm{N}$ of 65.2$)$. Recous et al. (1995) applied corn stover (C/N of 130) to a soil with mineral $\mathrm{N}$ concentration of $60 \mathrm{mg} \mathrm{kg}^{-1}$ and reported a maximum $\mathrm{N}$ immobilization of $55 \mathrm{mg} \mathrm{kg}^{-1}$. These differences in $\mathrm{N}$ immobilization when both a $\mathrm{C}$ source, e.g., cereal straw, and a $\mathrm{N}$ source, such as SS and pig slurry, are applied together to soil, must be related to initial soil $\mathrm{N}$ availability and biochemical composition of organic materials, especially related to their $\mathrm{C} / \mathrm{N}$ ratio.

At the end of 110 days of evaluation, soil from treatment $\mathrm{OSi}+\mathrm{SSi}$ contained $-13 \%$ mineral $\mathrm{N}$ compared to SSi treatment (113 vs $130 \mathrm{mg} \mathrm{kg}^{-1}$, respectively), considering that the mean difference in mineral $\mathrm{N}$ among these treatments throughout the experiment was $-27 \%$ (66 vs $84 \mathrm{mg} \mathrm{kg}^{-1}$ ). Based on the mean and maximum value of $\mathrm{N}$ immobilization determined for treatment OSi $+\mathrm{SSi}$ in relation to treatment SSi during incubation, the immobilized N/added $\mathrm{C}$ to treatment $\mathrm{OSi}+\mathrm{SSi}$ was calculated. The values for this ratio were $14.4 \mathrm{~kg} \mathrm{~N} \mathrm{Mg}^{-1} \mathrm{C}\left(5.9 \mathrm{~kg} \mathrm{~N} \mathrm{Mg}^{-1}\right.$ straw) and $8.6 \mathrm{~kg} \mathrm{~N} \mathrm{Mg}^{-1} \mathrm{C}$ (3.5 $\mathrm{kg} \mathrm{N} \mathrm{Mg}^{-1}$ straw), respectively. These results show that the combined application of SS and OS causes $\mathrm{N}$ immobilization, suggesting that in this situation the SS rate should be adjusted to ensure adequate $\mathrm{N}$ supply to plants. Although $\mathrm{N}$ 
immobilization was observed in treatment $\mathrm{OSi}+\mathrm{SSi}$, the quantity of soil mineral $\mathrm{N}$ of this treatment was always higher than that from the control treatment (S), indicating an increase in $\mathrm{N}$ availability even when organic materials were mixed with the soil.

Using the values of $\mathrm{N}$ mineralized in the SS treatment at the end of the experiment (Figure 3) and the quantities of organic $\mathrm{N}$ applied to soil with SS (Table 1), it is possible to calculate the percentage of applied organic $\mathrm{N}\left(171.1 \mathrm{mg} \mathrm{kg}^{-1}\right)$ that was mineralized (MF). After 110 days, approximately $60 \%$ of the organic $\mathrm{N}$ from SSi was mineralized. The SS has low energy load, being rich in readily degradable protein by microorganisms, which results in an increase of soil mineral $\mathrm{N}$ during the decomposition of this organic material (Rowell et al., 2001). This value of $\mathrm{N}$ mineralization obtained from SSi treatment in the present study is twice as high as that defined by Conama (2006) for aerobically digested SS. It is at the upper limit of a wide range of mineralization indices (24 to $59 \%$ ) determined in many different studies where aerobically treated SS was used (Serna and Pomares, 1992; Hernández et al., 2002; Gilmour et al., 2003; Doublet et al., 2010). Soil type and SS rate applied are factors that can affect the $\mathrm{N}$ mineralization index. In an experiment with two SS rates (30 and $50 \mathrm{~g} \mathrm{~kg}^{-1} \mathrm{SS}$ ) and two soil types (coarse- and fine-textured) from Spain, Hernández et al. (2002) observed that net $\mathrm{N}$ mineralization decreased with an increase in rate in the fine-textured soil. Another important factor contributing to SS-N mineralization is the type of treatment used for residual water stabilization (Serna and Pomares, 1992; Hernández et al., 2002). Furthermore, Gilmour et al. (2013) concluded that the stabilization period could be an important factor determining MF. Thus, results of Gilmour et al. (2003) and Parnaudeau et al. (2004) suggested that aside from the type of treatment, the SS stabilization period should be considered when defining MF of organic $\mathrm{N}$ from SS. These studies discuss the criteria adopted by Conama (2006) by which a fixed value for MF is defined for each SS class. Results of Serna and Pomares (1992) indicate that this strategy is inadequate, since the MF values varied, respectively, $14-45$ and $24-40 \%$ when analyzing organic $\mathrm{N}$ mineralization of six anaerobic and six aerobic sludges. This variation in MF values in each type of SS reinforces the importance of SS MF determination at each sewage treatment station, as determined by Resolution 375/2006 (Conama, 2006).

The quantity of SS used in incubation in this study was equivalent to $30 \mathrm{Mg} \mathrm{ha}{ }^{-1}$, which resulted in a total $\mathrm{N}$ application rate of $121 \mathrm{~kg} \mathrm{ha}^{-1}$. Of this amount, $18 \mathrm{~kg} \mathrm{ha}^{-1} \mathrm{~N}$ was in mineral form, mainly as ammonium (98\%) and $103 \mathrm{~kg} \mathrm{ha}^{-1} \mathrm{~N}$ in organic form. Considering the SS MF value of $64 \%$ found on this study, an extra $61.8 \mathrm{~kg} \mathrm{ha}^{-1} \mathrm{~N}$ would be transformed from organic to mineral form, resulting in a total of
$79.8 \mathrm{~kg} \mathrm{ha}^{-1}$ mineral $\mathrm{N}$. This quantity of potentially available $\mathrm{N}$ represents approximately $66 \%$ of the SS total applied $\mathrm{N}$. This value is three times higher than the SS-N efficiency index recommended by the Soil Chemistry and Fertility Commission (CQFS-RS/SC, 2004) for the first crop after SS application to soil. This result highlights the need for further research evaluating SS potential to supply $\mathrm{N}$ to crops to improve rate recommendations as a way of enhancing crop yields and decrease environmental impacts. Studies under laboratory and field conditions with a higher diversity of SS types from different sewage treatment stations and their combined use with crop straw are crucial to attain these goals. Inclusion of anaerobic SS in these studies is essential since the majority of sewage treatment stations in Brazil use an anaerobic digestion system, either alone or in association with stabilization ponds (Oliveira and Sperling, 2005).

\section{CONCLUSIONS}

Compared to sewage sludge alone, incorporation of a mixture of oats straw and sludge increased microbial nitrogen immobilization, suggesting that the sewage sludge rate should be increased to ensure adequate $\mathrm{N}$ supply to crops.

Increasing soil nitrogen availability by adding sewage sludge had no impact on the decomposition rate of oat straw.

The amounts of nitrogen mineralized during the decomposition of aerobic sewage sludge were twice greater than those proposed in the Resolution 375/2006 of the National Environmental Council (Conama).

\section{REFERENCES}

Aita C, Recous S, Cargnin RHO, Da Luz LP, Giacomini SJ. Impact on $\mathrm{C}$ and $\mathrm{N}$ dynamics of simultaneous application of pig slurry and wheat straw, as affected by their initial locations in soil. Biol Fertil Soils. 2012;48:633-42.

Andrade CA, Oliveira C, Cerri CC. Cinética de degradação da matéria orgânica de biossólidos após aplicação no solo e relação com a composição química inicial. Bragantia. 2006;65:659-68.

Comissão de Química e Fertilidade do Solo - CQFS-RS/SC. Manual de adubação e de calagem para os estados do Rio Grande do Sul e Santa Catarina. $10^{a}$.ed. Porto Alegre: Sociedade Brasileira de Ciência do Solo; 2004.

Conselho Nacional do Meio Ambiente - Conama. Resolução $\mathrm{n}^{\circ} 375$, de 29 de agosto de 2006. Define critérios e procedimentos, para o uso agrícola de lodos de esgoto gerados em estações de tratamento de esgoto sanitário e seus produtos derivados, e dá outras providências. Diário Oficial [da] República Federativa do Brasil, Brasília, DF, 30 ago. 2006. [Acessado em: 6 ago. 2012]. Disponível em: http://www.mma.gov.br/port/conama/legiabre. cfm?codlegi=506/normas_01.htm. 
Doublet J, Francou C, Pétraud JP, Dignac MF. Poitrenaud M, Houot, S. Distribution of $\mathrm{C}$ and $\mathrm{N}$ mineralization of a sludge compost within particle-size fractions. Bioresour Technol. 2010;101:1254-62.

Giacomini SJ, Aita C, Miola ECC, Recous S. Mineralização do carbono da palha de aveia e dejetos de suínos aplicados na superfície ou incorporados ao solo. R Bras Ci Solo. 2008;32:2661-8.

Giacomini SJ, Aita C, Pujol SB, Miola ECC. Transformações do nitrogênio no solo após adição de dejeto líquido e cama sobreposta de suínos. Pesq Agropec Bras. 2013;48:211-9.

Gilmour JT, Cogger CG, Jacobs LW, Evanylo GK, Sullivan DM. Decomposition and plant-available nitrogen in biosolids: laboratory studies, field studies, and computer simulation. J Environ Qual. 2003;32:1498-507.

Hernández T, Moral R, Perez-Espinosa A, Moreno-Caselles J, Perez-Murcia MD, García C. Nitrogen mineralisation potential in calcareous soils amended with sewage sludge. Bioresour Technol. 2002;83:213-9.

Oliveira SMAC, Sperling M von. Avaliação de 166 ETEs em operação no país, compreendendo diversas tecnologias. Parte 1 - análise de desempenho. Eng Sanit Amb. 2005;10:347-57.

Parnaudeau V, Nicolardot B, Pagès J. Relevance of organic matter fractions as predictors of wastewater sludge mineralization in soil. J Environ Qual. 2004;33:1885-94.
Recous S, Robin D, Darwis D, Mary B. Soil inorganic N availability: effect on maize residue decomposition. Soil Biol Biochem. 1995;27:1529-38.

Reinertsen SA, Elliott LF, Cochran VL, Campbell GS. Role of available carbon and nitrogen in determining the rate of wheat straw decomposition. Soil Biol Biochem. 1984;16:459-64.

Rowell DM, Prescott CE, Preston CM. Decomposition and nitrogen mineralization from biosolids and other organic materials: relationship with initial chemistry. J Environ Qual. 2001;30:1401-10.

Serna MD, Pomares F. Nitrogen mineralization of sludge amended soil. Bioresour Technol. 1992;39:285-90.

Sperling M von. Lodos ativados. Belo Horizonte: Universidade Federal de Minas Gerais; 1997.

Stotzky G. Microbial respiration. In: Black CA, Evans DD, White JL, editors. Methods of soil analysis. Madison: American Society of Agronomy; 1965. Pt 2, p.1550-72.

Swift MJ, Heal OW, Anderson JM. Decomposition in terrestrial ecosystem. Oxford: Blackwell; 1979.

Tedesco MJ, Gianello C, Bissani CA, Bohen H, Volkweiss SJ. Análises de solo, plantas e outros materiais. Porto Alegre: Universidade Federal do Rio Grande do Sul; 1995. 